\title{
Effective Technical Business In Agricultural Food Crops In Lamongan Regency
}

\author{
Sabilar Rosyad ${ }^{1}$ Yunni Rusmawati DJ ${ }^{2}$, Abid Muhtarom ${ }^{3}$ \\ \{Rosyadabil4@gmail.com.ac.id ${ }^{1}$,yunnirusmawati@unisla.ac.id ${ }^{2}$, abid@unisla.ac.id ${ }^{3}$ \} \\ Faculty of Economics, University Islamic of Lamongan, Indonesia ${ }^{1,2,3}$
}

\begin{abstract}
Food crop agriculture is the main source for people in Lamongan Regency. As a large community working in this primary sector and doing business in it. Land area, labor, and rainfall are the main capital of this sector, can be done by looking at changes in food crop agricultural productivity in Lamongan Regency. This study looks at the large level of technical efficiency using DEA (Data Envelopment Analysis) using the DEA Max sofeware requiring oriented output in 2010-2017. The estimation results of Lamongan Regency efficiency occurred in 2010, 2012, 2014, 2015 and 2016, while in 2011, 2013 and 2017 there was inefficiency.
\end{abstract}

Keywords: Land area, Labor, Rainfall, productivity and business.

\section{Introduction}

Indonesia is an area where as a large population livelihoods as farmers, so-called as an agricultural country. One of the agricultural areas that has become a rice barn in Indonesia is East Java province. Lamongan Regency is one of the 29 Regencies in East Java Province where most of its territory is dominated by agricultural land and the majority of its population are farmers. The agricultural area of Lamongan Regency is not only planted with rice, corn and others as superior crops, but there are planted crops that are needed throughout the year, especially food crops.

Food crop agriculture is the main production requirement of the people of Lamongan Regency as a result of productivity. However, the main problem of agriculture in Lamongan Regency is caused by many things, namely the area of agricultural land which continues to decline throughout the year, the number of workers throughout the year increases and also the problem of average high rainfall causes flooding in certain areas in Lamongan Regency. Increasingly productivity has continued to decline. The problem is that researchers want to see whether there is food crop agriculture inefficiency in Lamongan Regency or have the opposite effect because the above problems can be efficient.

According to [1] increasing efficiency and productivity of food crops tends to increase the chances of small (or subsistence) farmers to produce more food crops, where this can lead to increases in productivity and the level of their per capita income. This is due to an increase in the level of agricultural efficiency providing opportunities for farmers to produce more agricultural products at the same resource level, while productivity and efficiency directly affect by increasing the food supply available as stock and indirectly increasing household income. Likewise,[2] argue that the impact of poverty on increasing agricultural productivity growth is far greater than industry or sectoral services. 
To see and explain the problem of food crop agriculture, a good approach is needed, namely looking at efficiency. Efficiency of food crop agriculture is a fairly popular performance parameter used, efficiency measurement is widely used to answer difficulties in calculating measures of food crop agriculture. Calculation of the level of land area, labor, irrigation and rainfall is usually used to show good performance results, but this calculation is sometimes not included in the criteria of good food crop agriculture that can answer the problems of food crop agriculture. Measuring the efficiency of food crop agriculture can be done using parametric and nonparametric methods, in this case there are 2 approaches to calculating the efficiency of food crops, namely stochastic frontier analysis (SFA) and Data Envelopment Analysis (DEA) according to [3]. This study will use a nonparametric method using the DEA approach to analyze the level of efficiency of food crop agriculture from Lamongan Regency, East Java Province.

\section{Methodology}

This research uses a method namely Data Envelopment Analysis (DEA) to measure technical efficiency. DEA method is a non-parametric analysis method that aims to measure the level of technical efficiency relative to other production units that have the same objectives. The production unit is here in the form of a decision making unit (DMU) where the DMU in this study is a food crop agricultural sub-sector, Lamongan Regency, East Java Province, Indonesia.

This study focused on 8 years, namely in 2010 to 2017. The input variables used in this study were the total area of food crops, food crops, rainfall proxies while the productivity of food crop agriculture became the output variable. The Linear Programming (LP) function that is carried out in this approach uses the assumption of output oriented, so the objective function that is applied is the maximizing function of output with the input level which is ceteris paribus. DEA analysis of this one stage uses MaxDEA 7 Basic software.

In this measurement of technical efficiency, it will use output oriented measurement with one measurement scale assumption, namely Variable Return to Scale (VRS) with a DEA one stage approach. These assumptions are needed to be able to produce technical efficiency values in East Java Province Lamongan Regency, based on VRS assumptions, while also aiming to estimate the value of efficiency scores for each Lamongan Regency in East Java from 2010 to 2017.

The processed results of the technical efficiency measurement data will produce values with two conditions, namely efficient and inefficient regional conditions where it can be determined by looking at the DMU score or efficiency value. The technical efficiency score produced by the DEA method ranges from 0-1 where there are provisions as follows:

1. DMU efficiency score <1 (less than one) means that the DMU is relatively inefficient (inefficient) compared to other units in using inputs and producing output.

2. $\mathrm{DMU}=1$ (equal to one) efficiency score means that the DMU is relatively efficient compared to other units in using inputs and producing output.

The following is a model of technical efficiency analysis assuming VRS with the DEA one stage approach:

VRS Models Measurement Output Oriented Technical Efficiency 
$\operatorname{Max} \Phi, \lambda \Phi$,

s.t $-\Phi y i+Q \lambda \geq 0$

$\mathrm{xi}-\mathrm{X} \lambda \geq 0$

$\mathrm{I} 1^{\prime} \lambda=1$

$\lambda \geq 0$

where: $\Phi=$ efficiency score; $\lambda=\mathrm{Ix} 1$ vector constant or obstacle vector; $\mathrm{yi}=$ output vector $\mathrm{i} ; \mathrm{xi}=$ input vector $\mathrm{i} ; \mathrm{Q}=$ overall output matrix; $\mathrm{X}=$ input matrix i overall

The model above is a VRS model with an output-oriented approach in which the variable ukkan shows the calculation of technical efficiency [4]-[6] with a value of $\Phi$ between 1 up to $\infty$ (infinity), and $\Phi-1$ are proportional increases in output that can be achieved by DMU with constant input quantities. $\lambda$ is an vector Ix 1 of constants and $\mathrm{I} 1 \lambda=1$ is a convexity constraint, with I1 being a vector Ix 1 of one. Convexity constraints show that variable return to scale (VRS) which ensures that companies are inefficient will only be compared with companies that have the same scale. There is a note that $1 / \Phi$ indicates the value of technical efficiency which assumes values at interval levels 0 to 1 .

\section{Result}

\subsection{Agricultural land area Food crops in Lamongan Regency}

The area of agricultural food crops constitutes the majority of the area of Lamongan Regency. In 2010 the agricultural land area of food crops amounted to 82,826 hectares, in 2011-2012 agricultural food crops sequentially amounted to 82,786 hectares and 82,896 hectares. However, since 2013-2016 the food crop agricultural land of Lamongan Regency has continued to decline due to the problem of expert land functions, even in 2016, where a significant decrease in land area can be seen in Table I. The problem of experts in land functions does not only occur in the District Lamongan even all East Java Provinces [7], [8]

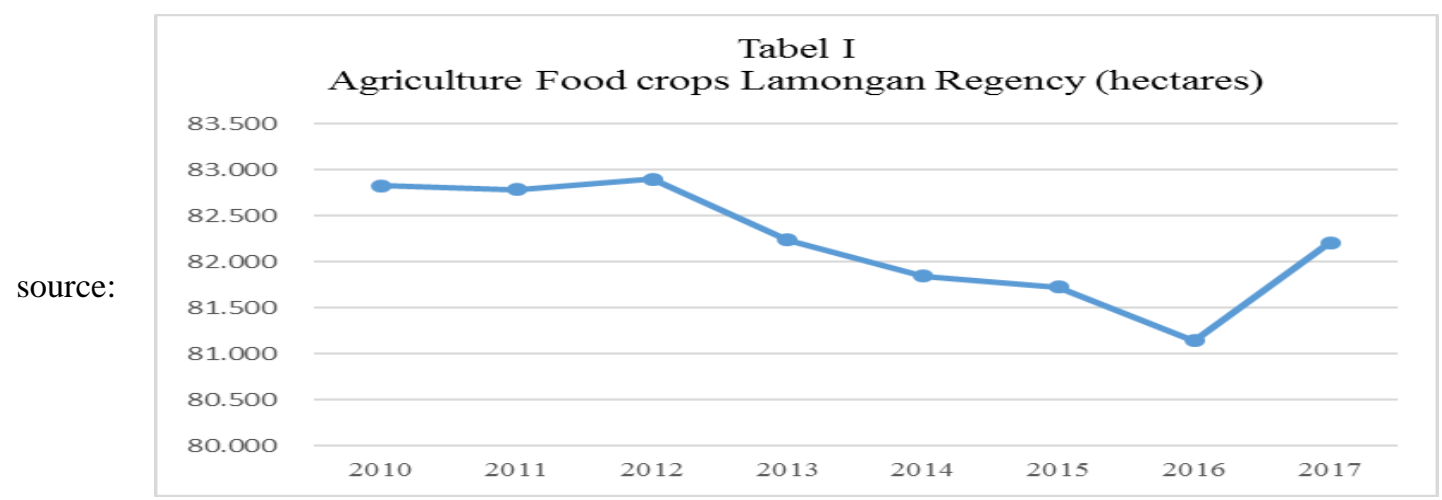

ministry of agriculture, processed

Declining agricultural land for the primary sector or natural resources, causing an economic shift to the tertiary sector has a positive and negative impact on society and even affects the productivity of agricultural crops. Negative impact is a decrease in the area of agricultural land due to experts in the function of land to the tertiary sector, the reduction of productive food crops so that it can affect the productivity of agricultural crops. 


\subsection{Agriculture for food crops in Lamongan Regency}

Labor is the most important factor in agricultural activities, especially agricultural food crops. The existence of a population also affects agricultural food crops. This is because the largest absorption of labor is in the agricultural sector of food crops. Lamongan Regency is

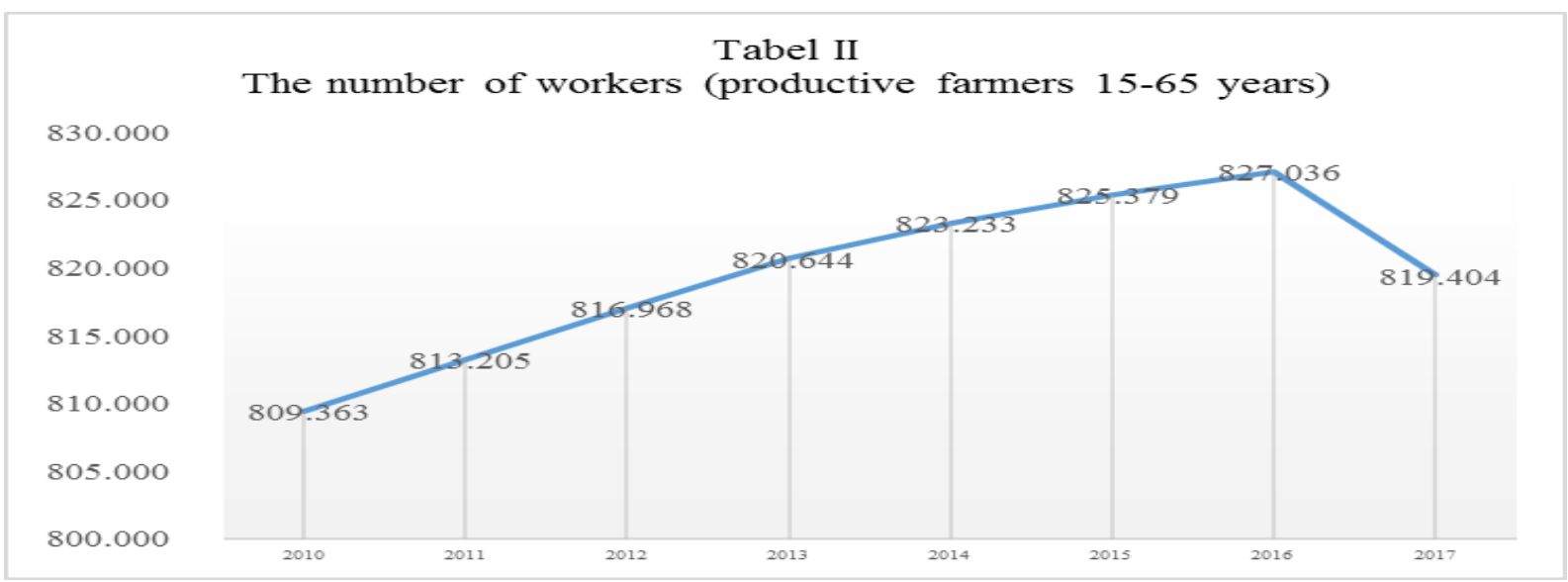

one of the Regencies in East Java Province which as a large part of the community earns a living as a farmer or agribusiness, so that the demand for labor is quite high. According to table II, it can be seen in the productive age of workers in the agricultural sector at the age of 15-86 years as follows:

source: ministry of agriculture, processed

From Table II, it can be seen that in 2010-2018 Laborers working in the food crop sector continued to increase even the biggest increase in 2016. This is because the food crop sector is the only business sector that can accommodate as many workers as possible, because in this sector no special skills are needed or only physical strength is needed. However, in 2017 there was a decrease in the number of workers in the food crop agriculture sector due to the large amount of agricultural land that turned into settlements and industries so that the young laborers in the agricultural sector turned to work in the industrial sector.

\subsection{Agricultural food crop rainfall in Lamongan Regency}

Climate in the form of rainfall is something that is important in food crop farming activities, but in this study researchers conducted proxy rainfall in Lamongan Regency. The need for rainfall is very important in the first time farming. But with the average amount of heavy rainfall it can adversely affect food crop agriculture. According to table III can be explained as follows:

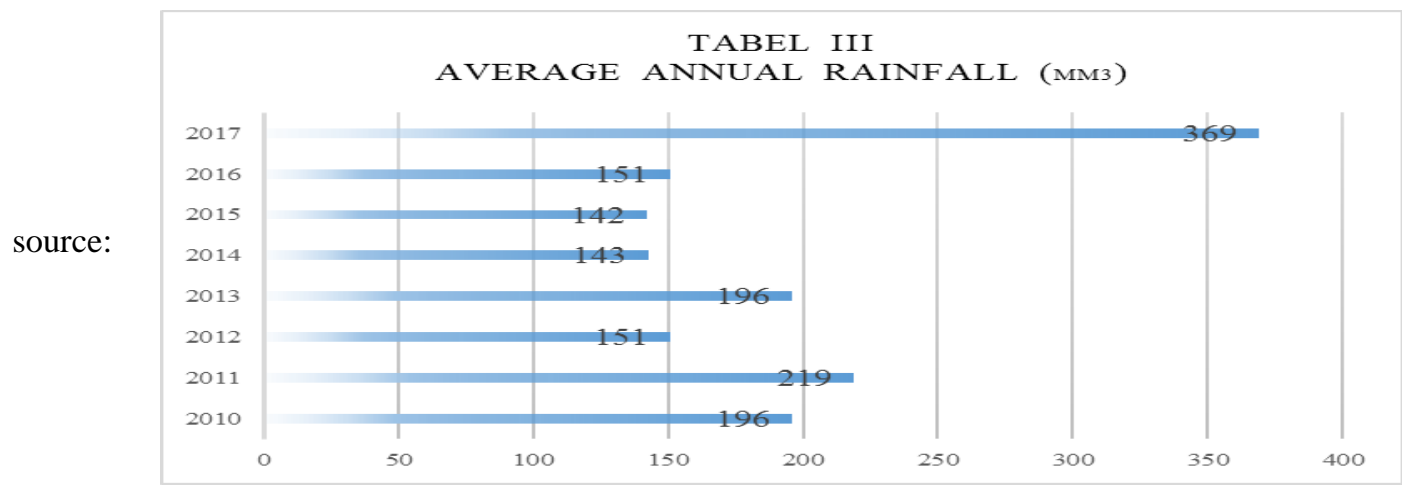


Lamongan Regency statistical center, processed

Lamongan Regency is a special area because if the rainfall is high, floods will occur, but if the summer is going to be difficult, the fresh water flows directly into the sea through the big river (Bengawan Solo). In Table III it can be explained if the average rainfall is above 150 $\mathrm{mm} 3$ per year, the flood indicator and this can have a negative impact on the food crop agriculture sector that occurred in 2010;2011; 2013 and 2017.

\subsection{Productivity of food crops agriculture Lamongan Regency}

Table VI illustrates the output of food crops in Lamongan Regency. Share data can be seen that in 2010-2013 productivity continued to decline due to the factors of productive agricultural land function experts to the tertiary sector.

source: Lamongan Regency statistical center, processed

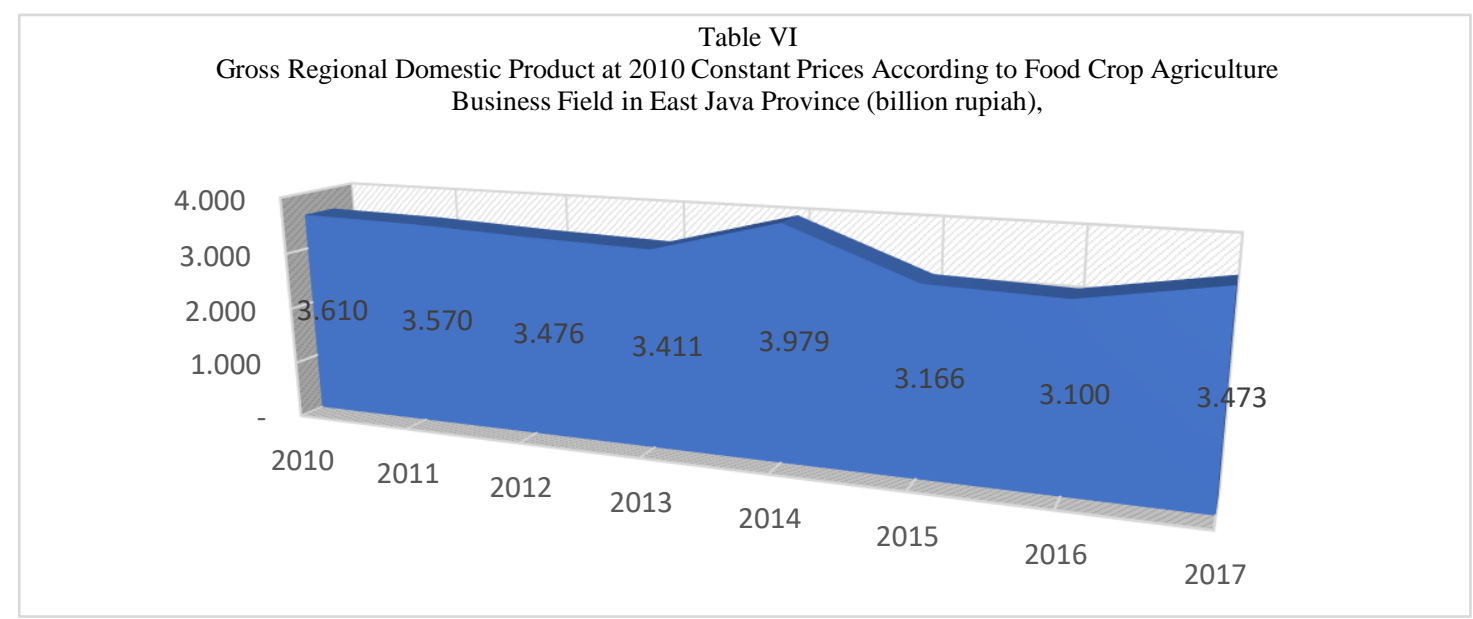

In 2014 Lamongan Regency food crop productivity increased significantly from 20102013 this was because the Lamongan regency community in the agricultural sector received handtractor and pump technology assistance from the government. However, in 2015-2017 there was a decline even under 2010-2013 due to the decreasing agricultural land from previous years.

\subsection{Estimated technical efficiency of the performance of food crops in Lamongan Regency}

The results of the estimation of technical efficiency for evaluating the performance of food crops in Lamongan Regency using the DEA basic method are shown in table V. The technical efficiency score ranges from 0 to 1 . Score 1 shows that the performance of food crops in Lamongan Regency has achieved efficient and agricultural conditions food crops operating on ineffective conditions have a technical efficiency score of less than 1. Based on Table V, it can be seen that in 2010-2017 62.5\% had an efficiency score and 37.5\% inefficiency scores. Has an average score of 0.909971333333333 inefficiency above 0.5 . On the other hand, the average efficiency score achieved in food crops in Lamongan Regency is 0.96623925, so it can be said that food crop agriculture in Lamongan Regency in 2010-2017 operates in an efficient manner and has the potential to increase output by 0.03376075 or $3.376075 \%$ again to achieve an efficient condition. 
Food crop agriculture Lamongan Regency has two sides of the chain which is the first opposite on the positive side is a fairly wide area of land compared to the number of workers who work in the agricultural sector [9], [10], the majority of residents who have higher and continues to grow so that the livelihoods of the agricultural sector will experience a decline but agricultural technology can turn it around [11]-[14], a strategic area in conducting business in the agricultural sector namely gerbangkertasusila so that it can improve development in the Lamongan Regency area, an integrated transportation system both regional and national roads [7], [8], [15].

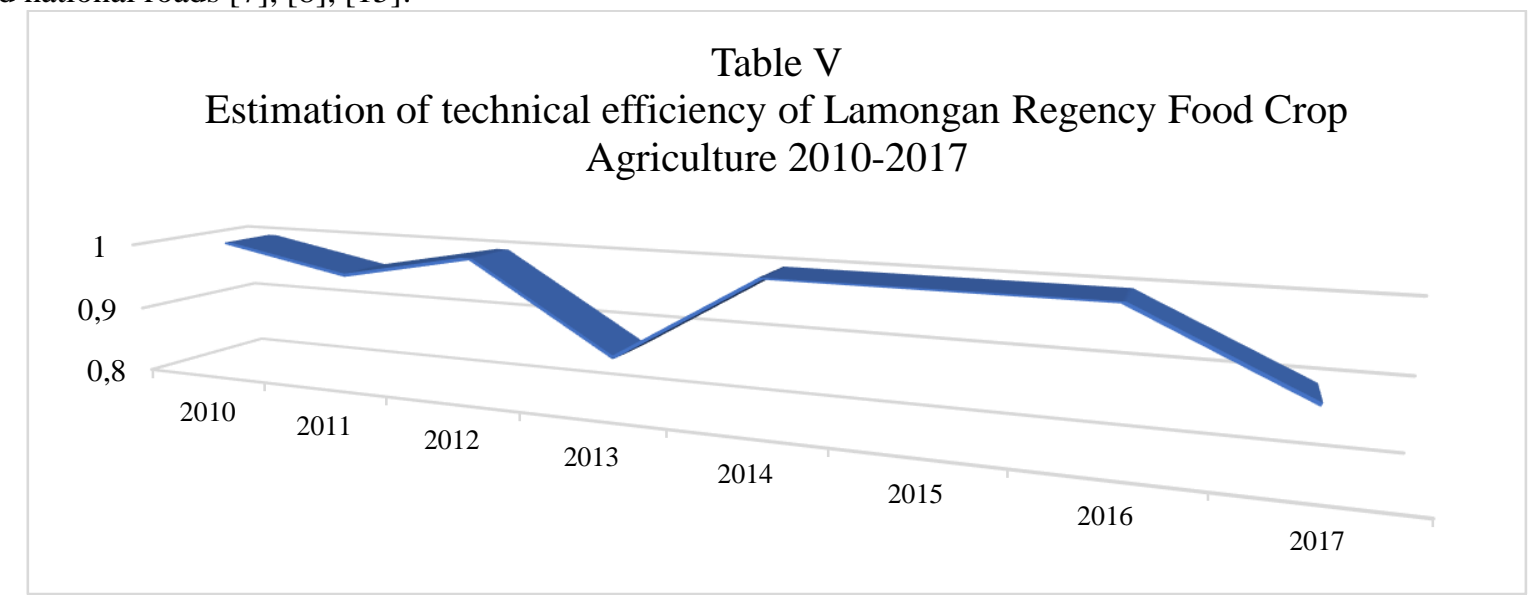

source: MaxDEA 7, processed

Negative Side of Agriculture Food crops in Lamongan Regency, namely the relatively fast growing population has an impact on the need for reduced agricultural land, resulting in land function experts [16], [17], focused activity concentration in Lamongan District, the region runs less optimally and special agricultural investment from the government is needed [18], agricultural businesses or businesses that are still not well organized by the government, thus affecting farmers' selling prices resulting in sustainable poverty [19].

\section{Conclusion}

Agriculture of food crops in Lamongan Regency is equal to 0.96623925 , so it can be said that food crop agriculture in Lamongan Regency in 2010-2017 operates in an efficient manner and has the potential to increase output by 0.03376075 or $3.376075 \%$ again to achieve an efficient condition. Activities that must be completed by food crop farming in Lamongan Regency are experts on land functions, businesses that have not run well, investments that have been pursued in the agricultural sector have not run optimally well because they focus on urban development.

Acknowledgments. Thanks to God, both parents, fellow writers, the extended family of the Lamongan Islamic University, the UNISLA Economic Faculty, UNISLA Research and Technology, friends of the UNAIR Doctor of Economics, CISC Lamongan, and parties who cannot be mentioned one by one

\section{References}


[1] J. L. G. S. R. and A. Warner, Economic growth and income of the poor, Harvard In. USA: Harvard Institute for International Development, 1998.

[2] M. Hannibal and G. Knight, "Additive manufacturing and the global factory: Disruptive technologies and the location of international business," Int. Bus. Rev., 2018.

[3] J. (Eds. . Cooper, William W., Seiford, Lawrence M., Zhu, Handbook on Data Envelopment Analysis, 2nd ed. Springer Science \& Business Media, Inc, 2011.

[4] G. E. Battese and T. J. Coelli, "A STOCHASTIC FRONTIER PRODUCTION FUNCTION INCORPORATING A MODEL FOR TECHNICAL INEFFICIENCY EFFECT ."

[5] M. Audibert, "Technical Inefficiency Effects among Paddy Farmers in the Villages of the "Office du Niger', Mali, West Africa," J. Product. Anal., 1997.

[6] G. E. Coelli, T.J., Rao, D.S.P., O’Donnell, C.J., Battese, An Introduction to Efficiency and Productivity Analysis, Second edi. New York: Springer Science \& Business Media, Inc, 2005.

[7] Abid Muhtarom; Tri Haryanto; Nurul Istifadah, "ANALYSIS OF PRODUCTIVITY EFFICIENCY OF FOOD PLANT AGRICULTURE IN EAST,” Int. J. Civ. Eng. Technol., vol. 10, no. 1 , pp. 420-443, 2019.

[8] A. Muhtarom and T. Haryanto, "Agriculture Land and Technology: Agricultural Production in the Welfare Improvement,” 2018.

[9] M. Bhattarai and A. Narayanamoorthy, "Impact of Irrigation on Agricultural Growth and Poverty Alleviation: Macro Level Analyses in India," India, 2003.

[10] N. Li, Y. Jiang, Z. Yu, and L. Shang, "Analysis of Agriculture Total-Factor Energy Efficiency in China Based on DEA and Malmquist indices," in Energy Procedia, 2017.

[11] L. Travers and J. Ma, "Agricultural productivity and rural poverty in China," China Econ. Rev., 1994.

[12] N. Majid, "Employment Strategy Papers Reaching Millennium Goals: How well does agricultural productivity growth reduce poverty?," 2004.

[13] X. Irz, L. Lin, C. Thirtle, and S. Wiggins, "Agricultural Productivity Growth and Poverty Alleviation," Overseas Development Institute, 2001.

[14] W. Song, Z. Han, and X. Deng, "Changes in productivity, efficiency and technology of China's crop production under rural restructuring," J. Rural Stud., 2016.

[15] S. Emran and F. Shilpi, "Agricultural Productivity, Hired Labor, Wages, and Poverty: Evidence from Bangladesh," World Dev., 2018.

[16] H. Kheir-El-Din and H. El-Laithy, "AGRICULTURAL PRODUCTIVITY GROWTH, EMPLOYMENT AND POVERTY IN EGYPT," 2008.

[17] N. Bayyurt and S. Y1lmaz, "The Impacts of Governance and Education on Agricultural Efficiency: An International Analysis," Procedia - Soc. Behav. Sci., 2012.

[18] A. Dhrifi, "Agricultural Productivity and Poverty Alleviation: What Role for Technological Innovation," J. Econ. Soc. Stud., 2014.

[19] A. Ogundipe, E. A. Oduntan, O. Adebayo, and K. Olagunju, "Agricultural Productivity, Poverty Reduction and Inclusive Growth in Africa: Linkages and Pathways," 2016. 